\title{
Regeneration of experimental long bone defect after implantation in its cavity of osteoplastic material "Calc-i-oss ${ }^{\circledR ”}$
}

\author{
KORENKOV O.V.*
}

\author{
Department of Human Anatomy, Sumy State University, 2, Rymskogo-Korsakova st., Sumy, Ukraine, 40007 \\ *E-mail: korenkov-alexsey@mail.ru
}

\begin{abstract}
Introduction: There is a significant divergence of data on the rate of resorption and replacement by the bone tissue of osteoplastic materials based on $\beta$-tricalcium phosphate in cancellous bone. At the same time in literature missing morphometric and electron microscopic features of bone tissue of the regenerate of compact substance of bone in these conditions. This study was aimed at the assessment of the healing of compact bone tissue defect after implantation of osteoplastic material "Calc-i-oss ${ }^{\circledR}$ " with the definition of the dynamics of resorption and morphological characteristics of bone tissue of the regenerate. Material and Methods: In the middle third of the diaphysis of the femur of rats there was reproduced the perforated defect to the bone-brain channel that was filled with osteoplastic material "Calc-i-oss ${ }^{\circledR}$ ". After surgery the fragments of injured bones were studied at the 60th and 120th day by methods of light microscopy with morphometry and scanning electron microscopy. Results: The conducted research revealed no inflammatory reaction at the site of the defect, signs of necrobiosis and necrosis of osteocytes in adjacent to the site of implantation maternal bone. The site of defect was filled with lamellar bone tissue high in osteoblasts, osteocytes and with integrated into its structure remains of "Calc-i-oss ${ }^{\circledR}$ ". On the surface and inside the implant there were found osteogenic cells and bone foci. It was established that the osteoplastic material throughout the observation period is subjected to development and replacement by bone tissue of the regenerate, the ratio of which on the 60th day of the experiment was $25.72 \pm 2.06 \%$ to $74.28 \pm 2.06 \%$, and on the 120 th day $-18.31 \pm 1.54 \%$ to $81.69 \pm 1.54 \%$. Conclusion: Osteoplastic material “Calc-i-oss ${ }^{\circledR}$ " exhibits biocompatibility, osteoconductive properties, ability to resorption and is replaced by bone tissue, with which it integrates well.
\end{abstract}

Keywords: femoral bone, $\beta$-tricalcium phosphate, reparative osteogenesis.

\section{Introduction}

Among the important problems faced by orthopedic doctors in their practices is tissue regeneration in the area of bone defects, which determines the need to find tools that would ensure their full healing. Transplantation of bone tissue to replace bone defects has a long history, which over the years made significant progress. However, because of the high frequency of complications that may arise after such operations, in recent years there is growing interest in the calcium-phosphate osteoplastic materials (HERMANOV, KAVALERSKY, CHERKASHINA et al., 2006; ZACEPIN, 2001). The similarity of chemical structure of similar materials with bone tissue and its inetness relatively to biological tissues make it possible to widely use them to replace the lost bone tissue (BARINOV and KOMLEV, 2005; PANKRATOV, LEKISHVILI and KOPETSKY, 2011).

The drug "Calc-i-oss ${ }^{\circledR}$ " and other drugs based on $\beta$-tricalcium phosphate by the time of its existence demonstrated high biocompatibility and excellent performance in the treatment of bone defects in orthopedics, traumatology, dentistry and maxillofacial surgery (MUSCHIK, LUDWIG, HALBHUBNER et al., 2001; WHEELER, 2005). However, despite the sufficiency of works that prove safety and biocompatibility of $\beta$-tricalcium phosphate, other determining properties of osteoplastic material, such as dynamics and its rate of biodegradation, replacement by the newly created bone tissue, have a significant divergence of data (SCHUGG, NIDEROST and SCHMIDLIN,
2002). In addition, the majority of works devoted to the study "Calc-i-oss ${ }^{\circledast}$ ", are related to morphological studies of trabecular bone, which is missing morphometric characteristics of histological preparations, the microscopic and especially electron microscopic features of the bone tissue of the regenerate (JENSEN, YEO, DARD et al., 2007; GOTTERBARM, BREUSCH, JUNG et al., 2014). Therefore, the purpose of our work - to explore the process of healing of the compact bone tissue defects after the implantation of osteoplastic material "Calc-i-oss ${ }^{\circledR}$ " using histological, morphometric and electron microscopic techniques.

\section{Material and Methods}

The experiment was performed on 24 white laboratory male rats of 8 months of age with a mass of $250 \pm 10$ grams keeping to the rules of "European Convention for the Protection of vertebrate animals used for experimental and other purposes." (KOZHEMYAKIN, KHROMOV, FILONENKO et al., 2002). Surgery was performed under general ketamine anesthesia $(0.3-0.5 \mathrm{ml}$ per $1 \mathrm{~kg}$ of rat) in aseptic conditions. With the help of dental boron in diameter of $2.5 \mathrm{~mm}$ at low speed and with cooling we reproduced the defect to the bone-brain channel inside the femur diaphysis, which without rigid fixation was filled osteoplastic material "Calc-i-oss ${ }^{\circledR}$ " ("Degradable Solutions Dental", Switzerland). The latter is an 
artificial granular material, which is made from pure synthetic $\beta$-tricalcium phosphate ( $\beta$-phase purity of $>99 \%, \mathrm{Ca} / \mathrm{P}-1,5$ ), with the general porosity of $50 \%$ and size of micropores of 1 to 6 microns (Figure 1 ) .

Next on the 60th and 120th day after surgery animals were taken out of the experiment by decapitation under deep ether anesthesia, followed by a study of injured bones using light microscopy with morphometry and scanning electron microscopy. Scanning electron microscopy was carried out on the electron microscope "SEM 106-I". Light microscopy of histological sections stained with hematoxylin-eosin, was carried out on the light microscope "OLIMPUS" followed by digital camera photographing of drugs, and morphometric analysis - using the program of image processing "video-Test" and "video-Size" (SARKISOV and PEROV, 1996). The latter consisted in determining on the 60th and 120th day of the experiment in the area of the defect of volume percent of bone, connective tissue and residual osteoplastic material as the ratio of the area of these components (\%) of the total area of the site of the defect $(100 \%)$. In addition, by using these methods, we investigated the state of the structure of adjacent to the site of implantation maternal bone in order to establish or refute postoperative complications due to the presence or absence of signs of necrobiosis and necrosis of osteocytes (GRIGORIAN and TOPORKOVA, 2007). The resulting digital values were treated statistically by calculating the arithmetic mean $(\mathrm{M})$ and its standard error $(\mathrm{m})$. The significance of differences between comparable performance was evaluated using Student t-test with the use of statistical computer program MS Excel XP. The difference was considered significant at $\mathrm{p}<0.05$ ( LAPACH, HUBENKO and BABICH, 2000).

\section{Results}

On the 60th day of the experiment all over the area of the site of the defect there appears lamellar bone tissue of the regenerate with integrated in its structure small remnants of osteoplastic material. In this case peripheral area of the defect was filled with the bone tissue that has a solid nature without the residue of "Calc-i-oss" ${ }^{\circledast ", ~ a n d ~ c e n t r a l ~-~ i n t e r m i t t e n t ~ n a t u r e, ~ b e t w e e n ~}$ the individual parts of which are the remains of osteoplastic material, and in the deeper cuts - even the elements of bone marrow (Figure 2). In the lacunae of the bone tissue there can be well traced osteocytes and osteoblasts with spikes, and inside and on the external surface the remains of osteoplastic material - osteogenic cells and osteogenesis foci. Near the blood vessels of the osteon channels there can be observed clusters (association) of osteoblasts and their predecessors that form well mineralized bone tissue (Figure 3 ). The area of the latter in the site of the defect is $74.28 \pm 2.06 \%$, while the number of osteoplastic material for 2 months of the experiment decreased to $25.72 \pm 2.06 \%$. In the area of the defect is not detected inflammatory response, and in the adjacent to it maternal bone there are bone lacunae with typical osteocytes with no signs of necrosis and necrobiosis.

On the 120th day of the experiment the area of osteoplastic material decreased by $28.81 \%(\mathrm{p}<0.05)$ compared to the previous period of monitoring and is $18.31 \pm 1.54 \%$ of the total area of the defect. In parallel to reduction of osteoplastic material there happened proportional increase of the bone tissue of the regenerate, whose area was $81.69 \pm 1.54 \%$. Inside and on the external surface of the left particles of osteoplastic material

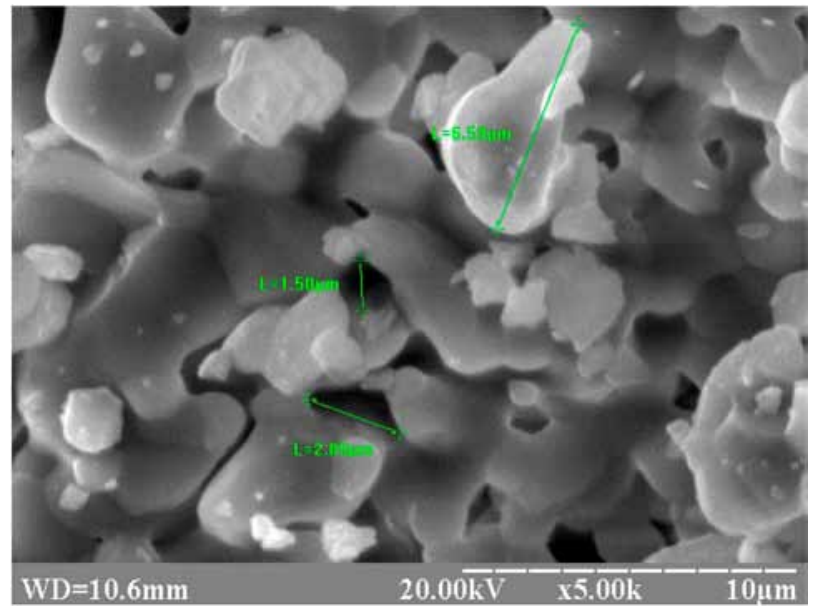

Figure 1. The microstructure of the osteoplastic material "Calc-i-oss ${ }^{\circledR}$ ". You can see mineral crystals measuring 6.59 microns and micropores between them ranging in size from 1.5 to 2.89 microns. Electronic scanning image. X 5000 .

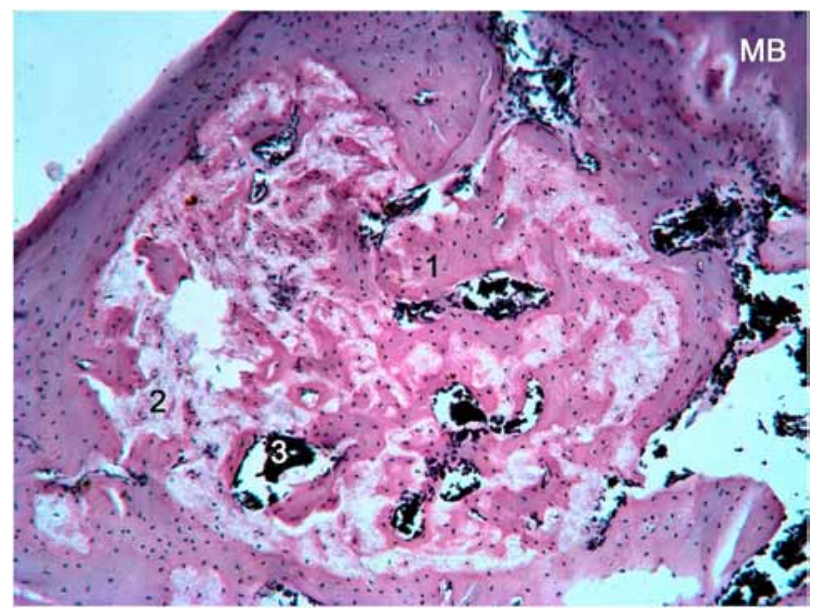

Figure 2. The area of the defect of rat femur on the 60th day after the implantation of "Calc-i-oss ${ }^{\circledR}$ ". Intermittent nature of the lamellar bone tissue of the regenerate ( 1 ) between the individual parts of which are the remains of osteoplastic material (2) and the elements of bone marrow (3). Maternal bone (MB) with typical osteocytes. H\&E X 50.

are osteogenic cells and osteogenesis foci. The newly formed lamellar bone tissue is characterized by the presence of the formed osteons and the fusion with the adjoining maternal bone, differing from the latter only by integrated into its structures remnants of osteoplastic material and bone marrow elements (Figure 4). In addition, in the composition of the bone tissue of the regenerate there are osteocytes with the long spikes, osteoblasts and moderate amount of osteoclasts which ensure its resorption. (Figure 5). In turn, the adjacent to the site of implantation maternal bone, as in the previous observation period, has typical osteocytes with no signs of necrobiosis and necrosis.

\section{Discussion}

The carried out microscopic examination of compact substance (diaphysis) of rats femur after implantation into their defect of osteoplastic material "Calc-i-oss ${ }^{\circledR}$ " has established 


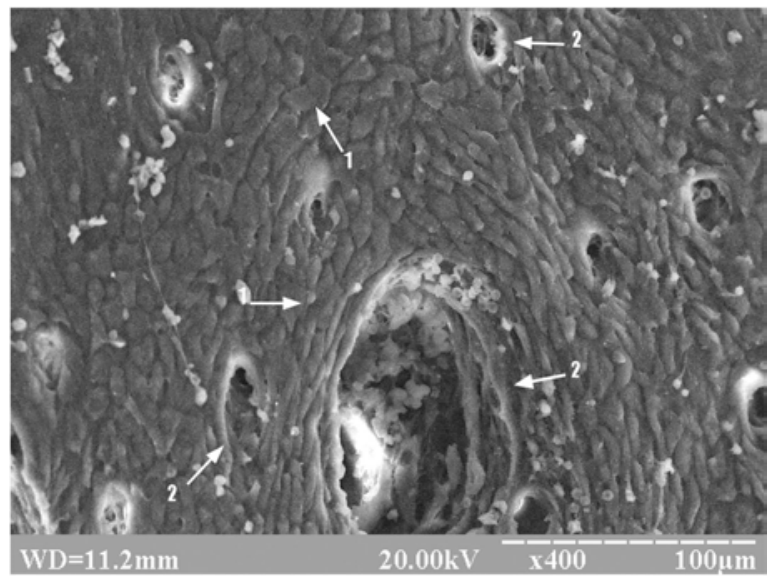

Figure 3. The area of the defect of rat femur on the 60th day after the implantation of "Calc-i-oss ${ }^{\circledR ”}$. Association of osteoblasts (1) near blood vessels (2) in place of the implant, which has undergone resorption. Electronic scanning image. X 400.

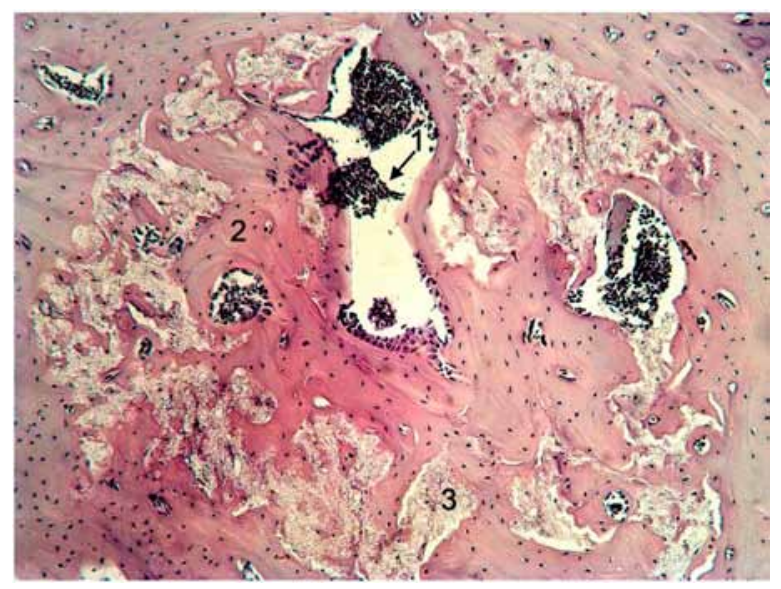

Figure 4. The area of the defect of rat femur on the 120th day after the implantation of "Calc-i-oss" ${ }^{\circledR}$ ". Bone marrow (1) and lamellar bone tissue of the regenerate (2) with integrated into its structure remnants of osteoplastic material (3). H\&E X 100.

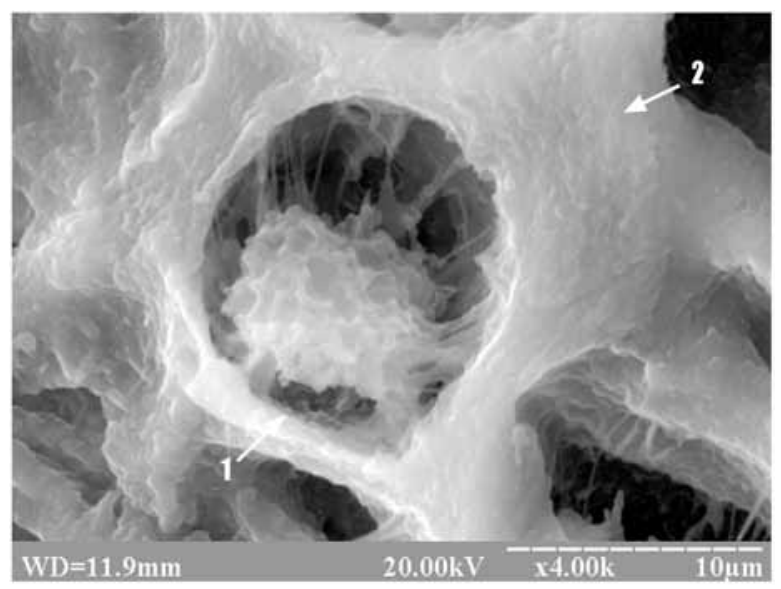

Figure 5. The area of the defect of rat femur on the 120th day after the implantation of "Calc-i-oss ${ }^{\circledR}$ ". Osteocytes with spikes (1) in the bone lacunae of lamellar osteogenic matrix (2), which was formed at the site of resorption of osteoplastic material. Electronic scanning image. X 4000. that the latter has a high biocompatibility, as evidenced by the absence of inflammatory reaction in the area of the defect and signs of necrobiosis and necrosis of osteocytes in adjacent to the site of implantation parent bone. Through the conducted experimental study there was set high tropism of cells of osteoclast and fibroblastic differons to osteoplastic material which were located on the surface and inside of the osteoplastic material. This fact is also evidence of osteo-conductive properties of the implant as osteogenic cells use "Calc-i-oss" ${ }^{\circledR}$ " as a platform to attach and generate on the surfaces and in its cavities of the new bone tissue (JENKINS, 2011). In addition, the microscopic examination revealed that bone tissue of the regenerate throughout the observation period has lamellar structure with a high content of typical osteoblasts, osteocytes and integrated into its structure remnants of osteoplastic material which is subjected to resorption. The good integration of "Calc-i-oss ${ }^{\circledR}$ " with the bone tissue of the regenerate is shown by its formation directly on the surface of osteoplastic material and its close immurement in its structures. The results of histological studies of other authors also show high biocompatibility of $\beta$-tricalcium phosphate, a good integration with its newly formed bone tissue and the ability to gradual resorption. However, its speed, according to the literature, has a significant divergence. Thus, Jensen, Yeo, Dard et al. (2007), established almost complete disappearance of $\beta$-tricalcium phosphate from the defect of mandibular angle of dwarf pigs on the 60th day, where its amount remained from 0 to $5.1 \%$ (average $2.5 \%$ ), and on the 180th day from 0 to $2.5 \%$ (average $0.8 \%$ ). At the same time, Gotterbarm, Breusch, Jung et al. (2014) found the remains of $\beta$-tricalcium phosphate $(4.35 \%)$, even a year after implantation with collagen in the defect of epiphysis of tubular bone of dwarf pigs. We also observed a gradual resorption of osteoplastic material and replacement by the bone tissue of the regenerate. However, in our experiment, the ratio of the implant and the bone tissue was $25.72 \pm 2.06 \%$ to $74.28 \pm 2.06 \%$ on the 60 th day and $18.31 \pm 1.54 \%$ to $81.69 \pm 1.54 \%$ on the 120 th day of the experiment. In the last period of the experiment there happened almost complete restoration of defect areas, as indicated by its filling with lamellar bone tissue that according to the structure is not very different from the parent bone. The only its difference lies in the presence of integrated in its structure remnants of osteoplastic material. At the same time resorption of the latter took place unevenly all over the area of the site of the defect, which was evidenced by almost complete absence of the implant in peripheral parts and the presence of more significant by the area remnants of osteoplastic material in the central parts of the area of the defect.

\section{Conclusion}

Thus, the found microscopic dynamics of the healing of the bone defect shows a high biocompatibility of material "Calc-i-oss ${ }^{\circledR}$ ", its osteo-conductive, the ability of the implant to resorption and replacement by the newly created bone tissue and good integration with it.

\section{References}

BARINOV, SM. and KOMLEV, VS. Bioceramics based on calcium phosphates. Moscow: Nauka, 2005. 308 p.

GOTTERBARM, T., BREUSCH, SJ., JUNG, M., STREICH, N., WILTFANG, J., BERARDI VILEI, S., RICHTER, W. and 
NITSCHE, T. Complete subchondral bone defect regeneration with a tricalcium phosphate collagen implant and osteoinductive growth factors: A randomized controlled study in Göttingen minipigs. Journal of Biomedical Materials Research, 2014, vol. 102, n. 5, p. 933-942.

GRIGORIAN, AS. and TOPORKOVA, AK. Problems of integration of implants in bone tissue (theoretical aspects). Moscow: Technosphere, 2007. 128 p.

HERMANOV, SH., KAVALERSKY, GM., CHERKASHINA ZA. and SEMENOV, VA. Bone-plastic surgery: from a bone graft to advanced biocomposite materials. Medical Assistance, 2006, n. 4, p. 16-19.

JENKINS, MJ. Polymers in biology and medicine. Moscow: Scientific World, 2011. $256 \mathrm{p}$.

JENSEN, SS., YEO, A., DARD, M., HUNZIKER, E., SCHENK, R and BUSER, D. Evaluation of a novel biphasic calcium phosphate in standardized bone defects A histologic and histomorphometric study in the mandibles of minipigs. Clinical Oral Implants Research, 2007, vol. 18 , n. 6 , p. $752-760$.

KOZHEMYAKIN, YM., KHROMOV, OS., FILONENKO, MA. and SAYFETDINOVA, GA. Scientific and practical advice on the keeping of laboratory animals and working with them. Kiev: Avicenna, 2002. 319 p.

LAPACH, SN., HUBENKO, AV. and BABICH, PN. Statistical methods in biomedical research using Excel. Kiev: Morion, 2000. 320 p.
MUSCHIK, M., LUDWIG, R., HALBHUBNER, S., BURSCHE, $\mathrm{K}$. and STOLL, T. $\beta$-Tricalcium phosphate as a bone substitute fordorsal spinal fusion in adolescent idiopathic scoliosis: preliminary result of a prospective clinical study. European Spine Journal, 2001, vol. 10, n. 2, p. 178-184.

PANKRATOV, AS., LEKISHVILI, MV. and KOPETSKY, IS. Bone grafting in dentistry and maxillofacial surgery: osteoplastic materials: a guide for physicians. Moscow: BINOM, 2011. 272 p.

SARKISOV, DS. and PEROV, YL. The microscopic technique. Moscow: Medicine, 1996. 544 p.

SCHUGG, J., NIDEROST, B. and SCHMIDLIN, P. Prävention der Alveolarkammatrophie nach Zahnextraktion durch Wurzelreplikas. Die Zahnarztwoche, 2002, vol. 47, n. 02, p. 14-15.

WHEELER, D. Grafting of massive tibial subchondral bone defects in a caprine model using: tricalcium phosphate versus autograft. Journal of Orthopaedic Trauma, 2005, vol. 19, n. 2, p. 85-91.

ZACEPIN, ST. Bone pathology of adults: guide for physicians. Moscow: Medicine, 2001. 450 p.

Received June 26, 2015

Accepted July 22, 2016 